\title{
Abnormal Earnings Persistence in the Jordanian Context
}

\author{
Firas Naim Dahmash ${ }^{1}$ \\ ${ }^{1}$ Accounting Department, the World Islamic Sciences \& Education University, Amman, Jordan \\ Correspondence: Firas Naim Dahmash, Accounting Department, the World Islamic Sciences \& Education \\ University, Amman, Jordan. E-mail: firas_dahmash@hotmail.com
}

Received: May 6, 2013

Accepted: May 30, 2013

Online Published: July 12, 2013

doi:10.5539/ijbm.v8n15p33

URL: http://dx.doi.org/10.5539/ijbm.v8n15p33

\begin{abstract}
This paper tested the abnormal earnings persistence in the Jordanian context through Ohlson's (1995) first Linear Information Dynamics (LID) Model using an unbalanced panel regression analysis for a sample of (840) public firms listed in the Amman Security Exchange during the period 2007 to 2011. The results showed a highly value relevance for the industrial, financial and services sectors indicated by the coefficient of the abnormal earnings persistence. The services sector had the highest value relevance. However, the industrial and the financial sectors were closed. Finally, the results for the detailed industry analysis of the sub-sectors had shown different values for the coefficient of the abnormal earnings persistence, and bank firms, printing \& packaging firms, and the utilities \& communication firms had the highest values for the coefficient of the abnormal earnings persistence.
\end{abstract}

Keywords: abnormal earnings persistence, Ohlson's (1995) linear information dynamics (LID) models, Jordanian context

\section{Introduction}

The periodical earnings of the firm represent a measure of its profitability, successful and performance. However, abnormal earnings represent the excess of these earnings over the required rate of return which is based on the book value of the firm. It is suggested that the unrecorded intangible assets (internally generated) might be the major source of abnormal earnings of the firm and the persistence of these abnormal earnings during the future financial periods of the firm (Kohlbeck \& Warfield, 2007). It was found also that the persistence of the abnormal earnings is positively related to earnings quality, and both of abnormal earnings persistence and earnings quality were considered as highly important indicators for making financial and economic decisions by many of the accounting information users including accountants, credit analysts and financial analysts (Siegal, 1982; Bricker, Flaherty \& O'Conner, 1995; Kim \& Choi, 1999; Jeon, S., Kang, K. \& Lee, $S, 2004)$.

Ohlson (1995) in his valuation model explains the persistence of abnormal earnings. The model suggested that firm value can be estimated through abnormal earnings and other information through the Linear Information Dynamics (LID) which represents one of the premises on which this valuation model is based, and this Linear Information Dynamics (LID) establishes the relationships of abnormal earnings persistence in the time series of the accounting profits. Acceptance of the premise of the Linear Information Dynamics (LID) enables the prediction of abnormal earnings for the following accounting period from the abnormal earnings of the current accounting period and other information. (Coelho, A., De Aguiar, A. \& Lopes, A, 2011). The other information is any relevant information which is not captured by accounting information, and this relevant information will impact the future abnormal earnings (Ohlson, 1995).

Some previous US and other international studies have tested the firm valuation model through abnormal earnings proposed by Ohlson (1995) for example: (Vazquez, Valdes and Valdes, 2007; Choi, O'Hanlon and Pope, 2006; Monahan, 2005; Walker and Wang, 2003; Dechow, Hutton and Sloan, 1999). However, and despite of the importance of other information variable for predicting future abnormal earnings, other information variable has been neglected in many previous studies which used the Ohlson (1995) valuation model, and according to that, they assumes that only the available publicly accounting information influences the valuation of the firm (Hand, 2001). However, some other researchers mostly in the US adopted the "Analysts Forecasts" to represent the "other information" variable (Dahmash \& Qabajeh, 2012). 
In the other hand, other researchers indicated that industry structure is expected to be a good source of other information, and this data source will affect the firm's future abnormal earnings (Owens, 2001). According to that, it is expected that industry structure will also affect the firm's abnormal earnings persistence, and different industry structures will cause a different effects on the persistence of abnormal earnings., so including industry structure data source in Ohlson's model mainly will increase its empirical content (Coelho, A., De Aguiar, A. \& Lopes, A., 2011).

This study will be oriented to apply the Linear Information Dynamics (LID) of Ohlson's (1995) model taking into consideration the different industry structures data as other affected information source to test the abnormal earnings persistence in the Jordanian context.

\section{Ohlson (1995) Model a Background}

Ohlson (1995) developed his model after modifying the residual income valuation model which implies that the value of the firm is equals to its book value of equity and the present value of anticipated abnormal earnings. Ohlson (1995) model, expressed the market value of a firm as a linear function of its book value, the abnormal earnings together with another information dynamics variable.

The Ohlson model was described under the following assumptions:

The Present Value Relation: This assumption implies that the market value of the firm's equity is equals to the present value of its expected future dividends discounted at the risk-free interest rate, and this assumption was based on the original classic dividend discount model.

The Clean Surplus Relation: This assumption implies that all changes in the book value of equity are reported either as accounting earnings or dividends. According to that the relation between book value of equity, earnings, and dividends can be expressed as follows:

$$
b_{t}=b_{t-1}+\chi_{t}-d_{t}
$$

Where $b_{t}=$ book value of equity at date $t ; \chi_{t}=$ earnings for period $t ; d_{t}=$ dividends paid at date $t$. According to Ohlson, book value of equity at date t-1 multiplied by the risk free rate is considered as the normal earnings of the firm. Then the earnings for the period t minus the normal earnings can be define as abnormal earnings.

$$
\chi_{t}^{a}=\chi_{t}-r b_{t}
$$

Where:

$\chi_{\mathrm{t}}^{\mathrm{a}}=$ abnormal earnings for period $\mathrm{t}$, (defined as above).

The Linear Information Dynamics: This assumption is the most controversial assumption which imposed a time-series structure on the abnormal earnings (that is, the relation between the current and the next period's abnormal earnings) as linear and stationary. Ohlson defines this abnormal relation as the difference between accounting earnings and normal earnings. Normal earnings are the net book value of equity multiplied by the risk free rate.

The linear information dynamic (models) which assumes a time-series structure on the abnormal earnings are as follows:

$$
\begin{gathered}
\chi_{t+1}^{a}=\omega_{11} \chi_{t}^{a}+v_{t}+\dot{\varepsilon}_{1 t+1} \\
v_{t+1}=\gamma v_{t}+\dot{\varepsilon}_{2 t+1}
\end{gathered}
$$

Where:

$\chi_{\mathrm{t}}^{\mathrm{a}}$ : Abnormal earnings of year $\mathrm{t}\left(\chi_{\mathrm{t}}^{\mathrm{a}}=\chi_{\mathrm{t}}-\mathrm{rb}_{\mathrm{t}}\right)$;

$v_{\mathrm{t}}$ : Other information variable at time $\mathrm{t}$;

$\omega_{11}$ : Persistence parameter of abnormal earnings $\left(0<\omega_{11}<1\right)$;

$\gamma$ : Persistence parameter of abnormal earnings $(0<\gamma<1)$;

$\dot{\varepsilon}_{1 \mathrm{t},} \dot{\varepsilon}_{2 \mathrm{t}}$ : Error terms.

Ohlson (1995) indicated that the error terms $\varepsilon_{1+1}, \varepsilon_{1+2}$, being $\tau \geq 1$, are unpredictable variables with an average of zero. The persistence parameters, $\omega_{11}$ and $\gamma$, are fixed and known, with the restriction of not to be negative and less than one (Coelho, A., De Aguiar, A. \& Lopes, A, 2011).

After the discussion of the abnormal earnings structure, Ohlson $(1995$, p.669) shows that with the standard assumptions underlying the dividend discount model together with the above mentioned Equations (1) and (2), his model equation can be written as follows: 


$$
P_{t}=b v_{t}+\alpha_{1} \chi_{t}^{a}+\alpha_{2} V_{t}
$$

Where:

$P_{t}$ : Is the market value of the firm's share equity for the fiscal year-end t.

$\mathrm{bv}_{\mathrm{t}}$ : Is the book value of the firm's share equity at the end of the fiscal year-end $t$.

$\chi_{\mathrm{t}}^{\mathrm{a}}$ : Is the abnormal earnings per firm's share during the year $\mathrm{t}$, (defined as above).

$\mathrm{V}_{\mathrm{t}}$ : Is other non-accounting value relevant information for the fiscal year-end $t$.

$\alpha_{1}, \alpha_{2}$ : Are coefficients taking values that are a function of the linear information dynamics models and the risk free rate for the firm (Ohlson, 1995; Ota, 1992; Vazquez, Valdes and Valdes, 2007; Dahmash and Qabajeh, 2012).

\section{Research Background}

Some previous research examines the determinants of abnormal earnings, and Ohlson (1995) Linear Information Dynamics (LID) Models. A recent Brazilian study by Coelho, De Aguiar and Lopes (2011) analyzed the Ohlson (1995) Linear Information Dynamics (LID) Models, and the effect of other information on the abnormal earnings series by using the industry structure and market share for a sample of Brazilian public companies. The results indicated that market share has no informational content, either directly or jointly on the degree of abnormal earnings persistence. However, the results confirm that different industries affect abnormal earnings persistence differently. Another recent Iranian study by (Khodadadi and Emami, 2009) aimed to determine the best method of panel data analysis for using Ohlson (1995) predicting model. The researchers ignored other information variable and tested four methods using panel data for a long period using a sample of firms listed on Tehran Stock Exchange. The results indicated that first method of pooled data analysis with period weight was the best in predicting abnormal earnings by Ohlson (1995) Model. Another study by Kohlbeck and Warfield (2007) examined the impact of unrecorded intangible assets on abnormal earnings and equity valuation in the context of the residual valuation model for publicly traded bank holding companies in the US. The results indicated that unrecorded intangible assets are important in understanding the valuation and the persistence of abnormal earning in the banking industry, and the persistence of bank abnormal earnings and, consequently, the pricing multiples on bank abnormal earnings, vary with the level of unrecorded intangible assets. In the contrary of the results of the recent study of Coelho, De Aguiar and Lopes (2011) concerning market share, Cheng (2005) found that both the level and the persistence of differential abnormal return on equity increase with firm size and market share. Another study by Khodadi et al. (2005) tested the validity of Ohlson (1995) Linear Information Dynamics (LID) Models through reviewing seven Linear Information Dynamics (LID) Models using time-series data for a sample of firms listed in Tehran Stock Exchange. The results indicated that the best linear information model is the same model presented by Ohlson (1995) which does not consider the other information variable on it. Jeon, Kang and Lee (2004) measured the persistence of abnormal earnings for manufacturing companies and hotels in Korea. The results indicated that the persistence of abnormal earnings was higher for hotels than manufacturing companies and for hotels of first class than other classes. Another study by Ota (2002) investigated the validity of the Ohlson (1995) Linear Information Dynamics (LID) Models and attempted to improve it without tackling the difficult task of specifying the other information variable. Ota (2002) transformed the Linear Information Dynamics (LID) Models to give seven empirically testable models. These models were tested using a sample of firms from Tokyo and Osaka Stock Exchanges. The results suggest that the modified LIDs (using generalized least squares) were generally superior to LIDs that omit the other information term. Myers (1999) examined the LIMs of Ohlson (1995) and Feltham and Ohlson (1995) using a large sample and a long period. Myers (1999) found that the LIDs provided value estimates no better than the book value alone. Myers (1999) also cautioned against modifying the LIDs by including analyst's forecasts as this can create internal inconsistencies.

Given the prior research findings discussed above, it is reasonable to expect that Ohlson's (1995) Linear Information Dynamics (LIDs) Models will be also successfully tested the abnormal earnings persistence within the Jordanian context over the period of this study.

\section{Method and Data}

This study aimed to answer the following research question:

Is there abnormal earnings persistence for the Jordanian public firms listed in Amman Security Exchange during the period between 2007 and 2011, and does the different Jordanian industry structures affect the firm's abnormal earnings persistence? 
In order to that, this study will apply the first Ohlson's (1995) Linear Information Dynamics (LIDs) Model as it is represented by Equation (3) above in the previous discussion which is as follows:

$$
\chi_{t+1}^{a}=\omega_{11} \chi_{t}^{a}+v_{t}+\dot{\varepsilon}_{1 t+1}
$$

Where:

$\chi_{\mathrm{t}}^{\mathrm{a}}$ : Abnormal earnings of year $\mathrm{t}$ (defined as the difference between earnings time $\mathrm{t}$, and the lagged book value $\mathrm{t}-1$ of the firm's equity multiplied by the risk free rate $\left(\chi_{\mathrm{t}}^{\mathrm{a}}=\chi_{\mathrm{t}}-\mathrm{rb}_{\mathrm{t}}\right)$,

$v_{t}$ : Other non-accounting value relevant information that will have impact in future abnormal earnings, time $t$,

$\omega_{11}$ : Persistence parameter of abnormal earnings which is fixed an known, with the restriction of not to be negative and less than one $\left(0<\omega_{11}<1\right)$,

$\dot{\varepsilon}_{1 \mathrm{t}}$ : Error term (Ohlson, 1995; Ota, 1992; Vazquez, Valdes and Valdes, 2007; Coelho, A., De Aguiar, A. \& Lopes, A, 2011; Dahmash and Qabajeh, 2012).

As discussed before, and in spite of the importance of the non-accounting value relevant information variable $\left(v_{t}\right)$, it is not clear what this "other information" variable might be exactly, and even Ohlson himself didn't clarify exactly what this variable might be. According to this fact many researchers neglected this variable in their studies and they assume that only the available publicly accounting information influences the valuation of the firm (Hand, 2001). In the other hand, some other researchers mostly in the US adopted the "Analysts Forecasts" to represent the "other information" variable (Dahmash \& Qabajeh, 2012).

Other previous studies mentioned that different industry structure data is expected to affect the firm's future abnormal earnings, and cause a different effects on the persistence of abnormal earnings (Owens, 2001; Coelho, A., De Aguiar, A., \& Lopes, A., 2011).

Based on the previous discussion, this study will apply the Ohlson's (1995) first Linear Information Model without the other information variable model taking into consideration the different industry structures data as other affected information source to test the abnormal earnings persistence in the Jordanian context for the following reasons:

(1) Many previous studies applied the first Linear Information Dynamics (LIDs) Model without the other information variable,

(2) The Jordanian data do not provide an "Analysts Forecasts" data.

(3) This study basically concentrated on the value relevance of the accounting variables.

(4) The results of applying the Ohlson (1995) first Linear Information Dynamics Model for this study shown a high explanation power (R-Square) which means that there is a little room for any "other information" variable.

(5) The results of applying the Ohlson (1995) first Linear Information Dynamics Model on a different industry structures for this study shown a different effects on the persistence of abnormal earnings.

The issue of what is the appropriate risk free rate is not constant between researchers, some researchers used the Capital Asset Pricing Model (CAPM) for this issue, and other researchers used the T-Bills Yield or annual return on saving (Dahmash \& Qabajeh, 2012). According to (Cheng, 2005) studies applied the (CAPM) as the cost of capital didn't deliver a significantly different results from those applied a risk free interest rate like the Treasury-Bills yield.

Based on these facts, this study will follow other previous studies, and will apply the annual return on saving calculated as the yearly weighted average interest rate for all types of bank deposits in Jordan as a proxy for the risk free rate, and this data was collected from the Center Bank of Jordan website.

Financial data incorporates all the Jordanian public firms listed on Amman Security Exchange which are consisting of the industrial sector firms, the services sector firms and the financial sector firms during the five-year period 2007 to 2011. All the book values were collected in a yearly basis as it is at the end of December from the published annual financial reports of these listed public firms from the Amman Security Exchange website.

The final sample of 840 observations is derived from a potential sample of 1046 selected as shown in Table 1 . 
Table 1. Sample selection

\begin{tabular}{lc}
\hline Years & $2007-2011$ \\
\hline Starting number of public firm years & 1046 \\
Less: & 206 \\
Public firms with missing and unavailable data & 840 \\
Final number of public firm years & \\
\hline
\end{tabular}

Table 2. Summary statistics

\begin{tabular}{lcc}
\hline (Variables) & $\chi_{\mathrm{t}+1}^{\mathrm{a}}$ & $\chi_{\mathrm{t}}^{\mathrm{a}}$ \\
\hline Pooled sample years (2007-2011) & \\
$N=840$ & & \\
Mean & 5 & 5 \\
Std. Dev. & 27 & 26 \\
Min & -65 & -64 \\
Max & 302 & 303 \\
\hline
\end{tabular}

This table reports summary statistics for variables used in the regression analysis reported in Table $3 \cdot \chi_{\mathrm{t}+1}^{\mathrm{a}}$ is the firm's abnormal earnings for the period $(\mathrm{t}+1)$ and $\chi_{\mathrm{t}}^{\mathrm{a}}$ is the firm's abnormal earnings for the period $(\mathrm{t})$. The variables are reported in millions of Jordanian currency (Dinars).

\section{Results}

Table 2 presented the summary statistics of the main two variables. The data covers a wide of industrial, commercial and financial public companies; the abnormal earnings variable of the pooled sample ranges from a minimum of -65 million Jordanian dinars to a maximum 302 million Jordanian dinars and a mean equal to 5 million Jordanian dinars, and a standard deviation equal to 27 million Jordanian dinars. The summary statistics of the lagged abnormal earnings variable of the pooled sample looks close to the summary statistics results of the abnormal earnings variable; the lagged abnormal earnings variable of the pooled sample ranges from a minimum of -64 million Jordanian dinars to a maximum 303 million Jordanian dinars and a mean value also equal to 5 million Jordanian dinars, and a standard deviation equal to 26 million dinars.

Table 3 presents the estimated regression for the Equation (5) using unbalanced panel analysis corrected for potential heteroscedasticity without altering the values of the coefficients by using heteroscedasticity-consistent estimators (following White, 1980).

Table 3. Assessing abnormal earnings persistence of Jordanian public firms using Ohlson's (1995) first linear information dynamics model

\begin{tabular}{lcccc}
\hline Years & $\begin{array}{c}(2007-2011) \\
\text { All Sectors }\end{array}$ & $\begin{array}{c}(2007-2011) \\
\text { Financial Sector }\end{array}$ & $\begin{array}{c}(2007-2011) \\
\text { Industrial Sector }\end{array}$ & $\begin{array}{c}(2007-2011) \\
\text { Services Sector }\end{array}$ \\
\hline Number of observations: & 840 & 288 & 298 & 254 \\
Constant C (Millions) & 0.749 & 1 & 1.91 & 0.089 \\
t-statistic (Ho: 0) & 1.460 & 1.203 & 1.721 & 0.212 \\
p-value & 0.145 & 0.230 & 0.087 & 0.833 \\
$\omega_{11}$ & 0.869 & 0.796 & 0.791 & 0.904 \\
t-statistic (Ho: 0) & 6.828 & 6.719 & 3.635 & 15.647 \\
p-value & 0.000 & 0.000 & 0.000 & 0.000 \\
Adj R Sq & 0.630 & 0.820 & 0.557 & 0.765 \\
F-Statistic & 7.517 & 14.479 & 5.920 & 14.055 \\
\hline
\end{tabular}

The regression results for the pooled sample presented in the first column of Table (3) confirm previous studies used Ohlson's (1995) first Linear Information Dynamics Model (Dechow, Hutton, and Sloan, 1999: Myers, 1999: Ota, 2002: Jeon, Kang and Lee, 2004: Khodadi et al., 2005: Khodadadi and Emami, 2009: Coelho, A., De Aguiar, A. \& Lopes, A, 2011) indicating that the coefficient of the abnormal earnings persistence $\left(\omega_{11}\right)$ is value relevant; that is, its coefficient is significantly greater than zero. 
It is noted that the abnormal earnings persistence $\left(\omega_{11}\right)$ of the pooled sample is high value relevant, and equal to 0.869 which means that there is high abnormal earnings persistence for the Jordanian public firms during the period of this study (2007-2011), and this high abnormal earnings persistence result might be caused by the unrecorded intangible assets (internally generated) which might be considered to be the major source of abnormal earnings of the firm and the persistence of these abnormal earnings during the future financial periods of the firm (Kohlbeck \& Warfield, 2007).

As a further robustness, and in order to see the industry structure effect on the abnormal earnings persistence on these public firms, another unbalanced panel analysis was done for the first financial sector sub-sample, second industrial sector sub-sample, and third services sector sub-sample respectively, and it can be seen from the second, third, and fourth columns in Table (3) above that the regression results are consistent with the regression results of previous pooled sample, and that's included the coefficients values of the abnormal earnings persistence for these three sub-samples, in addition to the (Adjusted R-Square) values.

Table (3) shown that the abnormal earnings persistence $\left(\omega_{11}\right)$ of the pooled sample is more value relevant than the abnormal earnings persistence $\left(\omega_{11}\right)$ of the financial sector and the industrial sector. However, the abnormal earnings persistence $\left(\omega_{11}\right)$ of the pooled sample is lower value relevant than the abnormal earnings persistence $\left(\omega_{11}\right)$ of the services sector. The coefficient for the abnormal earnings persistence $\left(\omega_{11}\right)$ of the pooled sample is 0.869 which is higher by 0.073 than the coefficient for the abnormal earnings persistence $\left(\omega_{11}\right)$ of the financial sector, and also higher by 0.078 than the coefficient for the abnormal earnings persistence $\left(\omega_{11}\right)$ of the industrial sector. As it is noted above, the coefficient for the abnormal earnings persistence $\left(\omega_{11}\right)$ of the pooled sample is lower by 0.035 than the abnormal earnings persistence $\left(\omega_{11}\right)$ of the services sector which has the higher coefficient for the abnormal earnings persistence $\left(\omega_{11}\right)$ comparing to the other two sub-samples. All these high results for abnormal earnings persistence coefficients might also be caused by the unrecorded intangible assets (internally generated) which might be considered to be the major source of abnormal earnings of the firm and the persistence of these abnormal earnings during the future financial periods of the firm (Kohlbeck \& Warfield, 2007).

These differences between the abnormal earnings persistence coefficients $\left(\omega_{11}\right)$ of the pooled sample and the other three sector samples, and between the three different services sectors (sub-samples) themselves indicated that industry structure is affecting the firm's abnormal earnings persistence, and different industry structures will cause a different effects on the persistence of abnormal earnings, and it might affecting the firm's future abnormal earnings in the same manner (Owens, 2001; Coelho, A., De Aguiar, A. \& Lopes, A, 2011).

Also, It should be noted that, consistent with previous studies using Ohlson (1995) first Linear Information Model for assessing abnormal earnings persistence (Dechow, Hutton, and Sloan, 1999: Myers, 1999: Ota, 2002: Jeon, Kang and Lee, 2004: Khodadi et al., 2005: Khodadadi and Emami, 2009: Coelho, A., De Aguiar, A. \& Lopes, A, 2011), the regression result for the pooled sample has high explanatory power (Adjusted R-Square of 87\%); indicated that the adoption of Ohlson's (1995) first Linear Information Dynamics Model in this study is highly relevant.

Another unbalanced panel analysis was made as robustness for the same pooled sample and the other three sub-samples by adding the logarithm of total assets as a control variable for size of the firms as many previous studies did.

It can also be seen from Table (4) that the same pooled sample, and also the same previous three sub-samples of the financial, industrial, and services sectors has approximately the same regression results of Table (3) and these results are consistent with the regression results of previous pooled, and sub-samples, and that's included the coefficients values of the abnormal earnings persistence for these samples and the (Adjusted R-Square) values, even after adding the new control variable of the logarithm of total assets as a control variable for size of these public firms. 
Table 4. Assessing abnormal earnings persistence of Jordanian public firms using Ohlson's (1995) first linear information dynamics model after adding the logarithm of total assets control variable

\begin{tabular}{|c|c|c|c|c|}
\hline Years & $\begin{array}{l}(2007-2011) \\
\text { All Sectors }\end{array}$ & $\begin{array}{c}(2007-2011) \\
\text { Financial Sector }\end{array}$ & $\begin{array}{c}(2007-2011) \\
\text { Industrial Sector }\end{array}$ & $\begin{array}{c}(2007-2011) \\
\text { Services Sector }\end{array}$ \\
\hline Number of observations: & 840 & 288 & 298 & 254 \\
\hline Constant C (Millions) & -17.914 & -18.626 & -58.989 & 1.139 \\
\hline t-statistic (Ho: 0) & -1.627 & -1.656 & -2.047 & 0.138 \\
\hline $\mathrm{p}$-value & 0.104 & 0.100 & 0.042 & 0.890 \\
\hline$\omega 11$ & 0.826 & 0.752 & 0.705 & 0.907 \\
\hline t-statistic (Ho: 0) & 6.223 & 5.900 & 3.241 & 13.770 \\
\hline $\mathrm{p}$-value & 0.000 & 0.000 & 0.001 & 0.000 \\
\hline $\log$ TA (Millions) & 2.524 & 2.563 & 8.494 & -0.142 \\
\hline t-statistic (Ho: 0) & 1.657 & 1.696 & 2.084 & -0.123 \\
\hline $\mathrm{p}$-value & 0.098 & 0.092 & 0.038 & 0.902 \\
\hline Adj R Sq & 0.648 & 0.823 & 0.572 & 0.764 \\
\hline F-Statistic & 8.014 & 14.617 & 6.160 & 13.766 \\
\hline
\end{tabular}

Finally a further unbalanced panel analysis was done for the detailed sub-sector (sub-sector analysis) for the financial sector, industrial sector, and services sector one by one to see industry structure effect for every sub-sector sample alone.

Table 5 shows the detailed financial sub-sector analysis for the same period of this study (2007-2011). Table 5 shows a different regression results for every financial sub-sector. The bank companies' sub-sector has the highest abnormal earnings persistence coefficient $\left(\omega_{11}\right)$ value of $97 \%$ which indicated the highest level of abnormal earnings persistence in the financial sector, and the Adjusted R-Square was also the best and the highest comparing to other financial sub-sector samples $80.9 \%$.

The results for the diversified financial companies sub-sample has lower abnormal earnings persistence coefficient $\left(\omega_{11}\right)$ value of $37.9 \%$ and a very low Adjusted R-Square value $5 \%$. Regression results for insurance companies sub-sector are not value relevant. It has a low abnormal earnings persistence coefficient $\left(\omega_{11}\right)$ value of $8.9 \%$ only and a negative Adjusted R-Square value equal to $-62.6 \%$.

The regression results for the final real state sub-sector are not much better than the insurance companies sub-sector regression results. It also not value relevant even thought it has an abnormal earnings persistence coefficient $\left(\omega_{11}\right)$ value of $36.9 \%$. The Adjusted R-Square value is also negative $-27.3 \%$.

Table 5. Assessing abnormal earnings persistence of Jordanian public financial sub-sector firms using Ohlson's (1995) first linear information dynamics model

\begin{tabular}{lcccc}
\hline Years & $\begin{array}{c}(2007-2011) \\
\text { Bank Companies }\end{array}$ & $\begin{array}{c}(2007-2011) \\
\text { Diversified Financial } \\
\text { Companies }\end{array}$ & $\begin{array}{c}(2007-2011) \\
\text { Insurance Companies }\end{array}$ & $\begin{array}{c}(2007-2011) \\
\text { Realstate Companies }\end{array}$ \\
\hline Number of observations: & 74 & 119 & 49 & 46 \\
Constant C (Millions) & -0.194 & -1.218 & 0.111 & 0.313 \\
t-statistic (Ho: 0) & -0.051 & -1.597 & 0.277 & 0.430 \\
p-value & 0.960 & 0.114 & 0.784 & 0.673 \\
(11 & 0.973 & 0.379 & 0.089 & 0.369 \\
t-statistic (Ho: 0) & 6.750 & 2.132 & 0.196 & 1.239 \\
p-value & 0.000 & 0.036 & 0.846 & 0.232 \\
Adj R Sq & 0.809 & 0.050 & -0.622 & -0.273 \\
F-Statistic & 16.438 & 1.165 & 0.292 & 0.655 \\
\hline
\end{tabular}

The unbalanced panel analysis for the same financial sub-sector sample was made after adding the same control variable of logarithm of total assets in order to control for the size effect, and the results were highly consistent with the previous results as shown in Table 6 below. 
Table 6. Assessing abnormal earnings persistence of Jordanian public financial sub-sector firms using Ohlson's (1995) first linear information dynamics model after adding logarithm of total assets control variable

\begin{tabular}{lcccc}
\hline Years & $\begin{array}{c}(2007-2011) \\
\text { Bank Companies }\end{array}$ & $\begin{array}{c}(2007-2011) \\
\text { Diversified Financial } \\
\text { Companies }\end{array}$ & $\begin{array}{c}(2007-2011) \\
\text { Insurance } \\
\text { Companies }\end{array}$ & $\begin{array}{c}(2007-2011) \\
\text { Realstate } \\
\text { Companies }\end{array}$ \\
\hline Number of observations: & 74 & 119 & 49 & 46 \\
Constant C (Millions) & -185.000 & 23.468 & -19.677 & -21.0451 \\
t-statistic (Ho: 0) & -1.616 & 1.553 & -1.061 & -0.932 \\
p-value & 0.112 & 0.124 & 0.301 & 0.365 \\
(11 & 0.813 & 0.348 & 0.020 & 0.383 \\
t-statistic (Ho: 0) & 4.482 & 2.214 & 0.055 & 1.184 \\
p-value & 0.000 & 0.030 & 0.957 & 0.254 \\
Log TA (Millions) & 20.830 & -3.358 & 2.731 & 2.902 \\
t-statistic (Ho: 0) & 1.602 & -1.583 & 1.068 & 0.943 \\
p-value & 0.115 & 0.118 & 0.298 & 0.360 \\
Adj R Sq & 0.819 & 0.091 & -0.562 & 33.780 \\
F-Statistic & 16.693 & 1.304 & 0.360 & 0.699 \\
\hline
\end{tabular}

Table 7 below shows detailed industrial sub-sector analysis for the same period of this study (2007-2011).

Table 7 shows also a different regression results for every industrial sub-sector. The food and beverages companies sub-sector has the highest abnormal earnings persistence coefficient $\left(\omega_{11}\right)$ value of $117.7 \%$ which considered a very high and unusual value, and indicated the highest level of abnormal earnings persistence in the industrial sector, and the Adjusted R-Square was also high, but not the highest comparing to other industrial sub-sector samples $72.5 \%$.

The printing and packaging industrial sub-sector has the second best results with a high abnormal earnings persistence coefficient $\left(\omega_{11}\right)$ value of $94.4 \%$ and also a high Adjusted R-Square value $80.9 \%$. Regression results for constructing and extracting companies sub-sector are also value relevant. The abnormal earnings persistence coefficient $\left(\omega_{11}\right)$ value of $76.8 \%$ and also a moderate Adjusted R-Square value 55.4\%. Finally, chemical and pharmaceutical industrial sub-sector results are also value relevant with an abnormal earnings persistence coefficient $\left(\omega_{11}\right)$ value of $30.1 \%$ and a low Adjusted R-Square value $10.6 \%$, and these are the lowest results values comparing to other industrial sub-sector samples.

Table 7. Assessing abnormal earnings persistence of Jordanian public industrial sub-sector firms using Ohlson's (1995) first linear information dynamics model

\begin{tabular}{lcccc}
\hline Years & $\begin{array}{c}(2007-2011) \\
\text { Chemical \& Pharmacetical }\end{array}$ & $\begin{array}{c}(2007-2011) \\
\text { Construction \& Extracting }\end{array}$ & $\begin{array}{c}(2007-2011) \\
\text { Food \& Beverages }\end{array}$ & $\begin{array}{c}(2007-2011) \\
\text { Printing \& Backaging }\end{array}$ \\
\hline Number of observations: & 64 & 127 & 66 & 41 \\
Constant C (Millions) & 0.131 & 4.614 & -1.650 & 0.021 \\
t-statistic (Ho: 0) & 0.621 & 1.640 & -0.652 & 0.216 \\
p-value & 0.538 & 0.104 & 0.518 & 0.831 \\
(11 & 0.301 & 0.768 & 1.177 & 0.944 \\
t-statistic (Ho: 0) & 1.749 & 3.747 & 8.145 & 10.266 \\
p-value & 0.087 & 0.000 & 0.000 & 0.000 \\
Adj R Sq & 0.106 & 0.554 & 0.725 & 0.809 \\
F-Statistic & 1.372 & 5.354 & 10.513 & 12.321 \\
\hline
\end{tabular}

As for the financial sub-sector samples, the unbalanced panel analysis for the same industrial sub-sector sample was made after adding the same control variable of logarithm total assets in order to control for the size effect, 
and the results were highly consistent with the previous results as shown in Table (8) below.

Table 8. Assessing abnormal earnings persistence of Jordanian public industrial sub-sector firms using Ohlson's (1995) first Linear Information Dynamics Model after adding logarithm of total assets control variable

\begin{tabular}{lcccc}
\hline Years & $\begin{array}{c}(2007-2011) \\
\text { Chemical \& } \\
\text { Pharmacetical }\end{array}$ & $\begin{array}{c}(2007-2011) \\
\text { Construction \& } \\
\text { Extracting }\end{array}$ & $\begin{array}{c}(2007-2011) \\
\text { Food \& Beverages }\end{array}$ & $\begin{array}{c}(2007-2011) \\
\text { Printing \& } \\
\text { Backaging }\end{array}$ \\
\hline Number of observations: & 64 & 127 & 66 & 41 \\
Constant C (Millions) & -7.727 & -98.977 & 3.934 & 1.309 \\
t-statistic (Ho: 0) & -2.172 & -2.285 & 0.474 & 0.456 \\
p-value & 0.036 & 0.025 & 0.638 & 0.652 \\
w11 & 0.191 & 0.629 & 1.222 & 0.978 \\
t-statistic (Ho: 0) & 1.250 & 3.097 & 6.718 & 8.250 \\
p-value & 0.218 & 0.003 & 0.000 & 0.000 \\
Log TA (Millions) & 1.121 & 14.303 & -0.568 & -0.185 \\
t-statistic (Ho: 0) & 2.193 & 2.354 & -0.488 & -0.445 \\
p-value & 0.034 & 0.021 & 0.628 & 0.661 \\
Adj R Sq & 0.186 & 0.580 & 0.721 & 0.805 \\
F-Statistic & 1.685 & 5.698 & 9.847 & 11.295 \\
\hline
\end{tabular}

Table 9 below shows detailed services sub-sector analysis for the same period of this study (2007-2011). Table 9 shows also a different regression results for every services sub-sector.

The utilities and communication companies sub-sector has the highest abnormal earnings persistence coefficient $\left(\omega_{11}\right)$ value of $101.7 \%$ which considered a very high and unusual value similar to food and beverages industrial sub-sector, and this value indicated the highest level of abnormal earnings persistence in the services sector, and the Adjusted R-Square was also the highest comparing to other services sub-sector companies with a value of $97 \%$.

The commercial and educational services sub-sector has the second best results with a high abnormal earnings persistence coefficient $\left(\omega_{11}\right)$ value of $79 \%$ and an Adjusted R-Square value 56.4\%. Regression results for tourism and health care companies sub-sector are also value relevant, but less than those of the commercial and educational services sub-sector companies. The abnormal earnings persistence coefficient $\left(\omega_{11}\right)$ value $42.2 \%$ with an Adjusted R-Square value of 23.2\%. Finally, transportation services sub-sector results was not value relevant with a negative abnormal earnings persistence coefficient $\left(\omega_{11}\right)$ value of $-69.8 \%$ and a low Adjusted R-Square value $18.1 \%$, and these are the lowest results values comparing to other services sub-sector samples.

Table 9. Assess abnormal earnings persistence of Jordanian public services sub-sector firms using Ohlson's (1995) first linear information dynamics model

\begin{tabular}{|c|c|c|c|c|}
\hline Years & $\begin{array}{c}\text { (2007-2011) } \\
\text { Utilities \& } \\
\text { Communications }\end{array}$ & $\begin{array}{c}\text { (2007-2011) } \\
\text { Transportation } \\
\text { Services } \\
\end{array}$ & $\begin{array}{c}(2007-2011) \\
\text { Tourism \& Health } \\
\text { Care }\end{array}$ & $\begin{array}{c}(2007-2011) \\
\text { Commercial \& Educational } \\
\text { Services }\end{array}$ \\
\hline $\begin{array}{l}\text { Number } \\
\text { observations: }\end{array}$ & 45 & 60 & 66 & 83 \\
\hline Constant C (Millions) & 0.359 & 0.058 & 0.354 & 0.313 \\
\hline t-statistic (Ho: 0) & 0.462 & 0.057 & 1.458 & 1.080 \\
\hline p-value & 0.648 & 0.955 & 0.152 & 0.285 \\
\hline$\omega 11$ & 1.017 & -0.698 & 0.422 & 0.790 \\
\hline t-statistic (Ho: 0) & 37.617 & -1.825 & 2.280 & 7.872 \\
\hline p-value & 0.000 & 0.076 & 0.027 & 0.000 \\
\hline Adj R Sq & 0.970 & 0.181 & 0.232 & 0.564 \\
\hline F-Statistic & 90.138 & 1.688 & 1.981 & 5.078 \\
\hline
\end{tabular}

As for the financial sub-sector samples, and the industrial sub-sector samples the unbalanced panel analysis for 
the same services sub-sector sample was made after adding the same control variable of logarithm total assets in order to control for the size effect, and the results were highly consistent with the previous results as shown in Table 10 below.

Table 10. Assessing abnormal earnings persistence of Jordanian public services sub-sector firms using Ohlson's (1995) first linear information model after adding logarithm of total assets control variable

\begin{tabular}{|c|c|c|c|c|}
\hline Years & $\begin{array}{c}\text { (2007-2011) } \\
\text { Utilities \& } \\
\text { Communications } \\
\end{array}$ & $\begin{array}{c}(2007-2011) \\
\text { Transportation } \\
\text { Services } \\
\end{array}$ & $\begin{array}{c}(2007-2011) \\
\text { Tourism \& Health } \\
\text { Care }\end{array}$ & $\begin{array}{c}(2007-2011) \\
\text { Commercial \& Educational } \\
\text { Services }\end{array}$ \\
\hline $\begin{array}{l}\text { Number } \\
\text { observations: }\end{array}$ & 45 & 60 & 66 & 83 \\
\hline Constant C (Millions) & -13.527 & 8.464 & -5.234 & 0.110 \\
\hline t-statistic (Ho: 0) & -1.470 & 0.274 & -1.308 & 0.023 \\
\hline p-value & 0.153 & 0.786 & 0.198 & 0.982 \\
\hline$\omega 11$ & 1.001 & -0.677 & 0.315 & 0.789 \\
\hline t-statistic (Ho: 0) & 32.516 & -1.875 & 1.536 & 7.442 \\
\hline p-value & 0.000 & 0.068 & 0.132 & 0.000 \\
\hline $\log T A$ & 1.758 & -1.142 & 0.762 & 0.028 \\
\hline t-statistic (Ho: 0) & 1.469 & -0.268 & 1.373 & 0.040 \\
\hline p-value & 0.153 & 0.790 & 0.177 & 0.968 \\
\hline Adj R Sq & 0.971 & 0.165 & 0.253 & 0.556 \\
\hline F-Statistic & 87.752 & 1.581 & 2.050 & 4.803 \\
\hline
\end{tabular}

\section{Conclusions}

This study examined the abnormal earnings persistence by using Ohlson (1995) first Linear Information Model for all the Jordanian industrial, commercial and financial public firms listed in Amman Security Exchange during the period 2007 to 2011 .

Unbalanced panel analysis regression corrected for potential heteroscedasticity was used to examine the validity of the model. Based on the results of the study, the following conclusions can be made:

First, The Ohlson (1995) first Linear Information Model shown a highly value relevant for the Jordanian industrial, commercial and financial public firms listed in Amman Security Exchange during the period 2007 to 2011.

Second, the results showed that the coefficient of the abnormal earnings persistence is value relevant for the pooled sample and the three sub-samples, and the results were consistent.

Third, the coefficient value of the abnormal earnings persistence for the services sector was the highest between the three sub-samples, and the coefficient value of the abnormal earnings persistence for the industrial sector was closed to the financial sector.

Fourth, the detailed industry analysis results for the sub-sectors of the sample firms had shown different values for the coefficient of the abnormal earnings persistence, and bank firms, printing \& packaging firms, and the utilities \& communication firms had the highest values for the coefficient of the abnormal earnings persistence.

\section{References}

Amman Security Exchange (ASE). (2007-2011). Annual Reports. Retrieved from http://www.ase.com.jo

Bricker, L., Flaherty, R., \& O'Conner, M. (1995). Financial analysts assessment of company earnings quality. Journal of Accounting Auditing and Finance, 10(3), 541-554.

Central Bank of Jordan (CBJ). (2007-2011). Annual and semi-annual interest rates for banks. Retrieved from http://www.cbj.com.jo

Cheng, Q. (2005). What determines residual income? The Accounting Review, 80(January), 85-112. http://dx.doi.org/10.2308/accr.2005.80.1.85

Choi, Y., O'Hanlon, J., \& Pope, P. F. (2001). Linear information models in residual income based valuation: a development of the Dechow, Hutton and Sloan empirical approach'. Working Paper, Lancaster University. 
Coelho, A., De Aguiar, A., \& Lopes, A. (2011). Relationship between abnormal earnings persistence, industry structure, and market share in Brazilian public firms. Brazilian Administration Review, 8(1), 48-67. http://dx.doi.org/10.1590/S1807-76922011000100005

Dahmash, F. N., \& Qabajeh, M. (2012). Value relevance of Ohlson model with Jordanian data. Interdisciplinary Journal of Contemporary Research in Business, 3(11), 551-560.

Dechow, P. M., Hutton, A. P., \& Sloan, R. G. (1999). An empirical assessment of the residual income valuation $\begin{array}{llllll}\text { model. Journal of Accounting \& Economics, } & \text { 26(1-3), }\end{array}$ http://dx.doi.org/10.1016/S0165-4101(98)00049-4

Feltham, G. A., \& Ohlson, J. A. (1995) Valuation and clean surplus accounting for operating and financial activities. Contemporary Accounting Research, 11, 689-731. http://dx.doi.org/10.1111/j.1911-3846.1995.tb00462.x

Hand, J. R. (2001). Discussion of earnings, book values, and dividends in equity valuation: An empirical perspective. Contemporary Accounting Research, 18(1), 121-130. http://dx.doi.org/10.1506/6A7C-74ML-TGBD-DYBW

Jeon, S., Kang, K. \& Lee, S. (2004). The relationship between persistence of abnormal earnings and usefulness of accounting information in hotel companies. Torism Management, 25, 735-740. http://dx.doi.org/10.1016/j.tourman.2003.09.010

Khodadadi, V., Dastgir, M., Norvash, I., \& Momeni, M. (2005). Design of Linear Information Model in Tehran Stock Exchange: Expansion of Ohlson model. PhD thesis, Faculty of Management, Tehran University.

Khodadadi, V., \& Emami, M. R. (2009). Using Panel Data Analysis Methods in Ohlson (1995) Model to Predicting Abnormal Earnings. International Bulletin of Business Administration, 6, 40-49. http://dx.doi.org/10.2308/acch.2007.21.1.23

Kim, M., \& Choi, K. (1999). Earnings quality. Korea Accounting Journal, 8(2), 221-245.

Kohlbeck, M., \& Warfield, T. (2007). Unrecorded intangible assets: Abnormal earnings and valuation. Accounting Horizons, 21(1), 32-41.

Monahan, S. J. (2005). Conservatism, growth and the role of accounting numbers in the fundamental analysis process. Review of Accounting Studies, 10(2-3), 227-260. http://dx.doi.org/10.1007/s11142-005-1530-8

Myers, J. (1999). Implementing residual income valuation with linear information dynamics. The Accounting Review, 74, 1-28. http://dx.doi.org/10.2308/accr.1999.74.1.1

Ohlson, J. (1995). Earnings, book values, and dividends in equity valuation. Contemporary Accounting Research, 11, 661-687. http://dx.doi.org/10.1111/j.1911-3846.1995.tb00461.x

Ota, K. (2002). A test of the Ohlson (1995) model: empirical evidence from Japan. The International Journal of Accounting, 37(2), 157-182. http://dx.doi.org/10.1016/S0020-7063(02)00150-4

Owens, L. A. (2001). An examination of the relationships between strategy, environment, and performance in a fundamental analysis model. Doctoral dissertation, Oklahama State University, Stillwater, OK, USA.

Siegal, J. (1982). The quality of earnings concept-a survey. Financial Analyst Journal, 38(2), 60-68. http://dx.doi.org/10.2469/faj.v38.n2.60

Vazquez, R. D., Valdes, A. L., \& Valdes, H. V. (n.d.). Value relevance of the Ohlson model with Mexican data. Universidad Nacional Autonma de Mexico. Working Paper.

Walker, M., \& Wang, P. (2003). Towards an understanding of profitability analysis within the residual income valuation framework. Accounting and Business Research, 33(3), 235-246. http://dx.doi.org/10.1080/00014788.2003.9729648

White, H. (1980). A heteroskedasticity consistent covariance matrix estimator and a direct test for heteroskedasticity. Econometrica, 48(4), 817-838. http://dx.doi.org/10.2307/1912934

\section{Copyrights}

Copyright for this article is retained by the author(s), with first publication rights granted to the journal.

This is an open-access article distributed under the terms and conditions of the Creative Commons Attribution license (http://creativecommons.org/licenses/by/3.0/). 